\title{
THE INFLUENCE OF VITAMIN A UPON UREA CLEARANCE IN THE HUMAN SUBJECT ${ }^{1}$
}

\author{
BY RAYMOND C. HERRIN AND HENRY J. NICHOLES \\ (From the Department of Physiology, University of Wisconsin, Madison)
}

(Received for publication December 29, 1939)

The object of this study was to ascertain the effect upon the urea clearance of the addition of large amounts of vitamin $A$ to the ordinary mixed diet of normal subjects.

\section{METHODS}

The subjects presented no evidence or history of serious renal disease. Nine of the subjects were male medical students. Subject 4 was a 48 -year-old female patient, showing severe signs of vitamin A deficiency. Three were staff members of the physiology department. The clearances were conducted about 15 hours after the last meal. Approximately a liter of water was drunk about an hour before the clearance periods. During the clearance periods from 500 to $1000 \mathrm{cc}$. of water were taken. Urine collection was not begun until $200 \mathrm{cc}$. of urine had been passed. This eliminated the possibility of washing out concentrated urine from the dead space of the urinary system. Periods in which the rate of urine flow was rising were avoided or rejected. In the first 7 subjects in Table I the bladder was catheterized and washed with sterile saline before and at the end of each collection period. In the remaining subjects, the bladder was not regularly catheterized because the maximum retention after voluntary micturition was never found to be greater than $5 \mathrm{cc}$., and with a urine volume between $150 \mathrm{cc}$. and $400 \mathrm{cc}$. the error was negligible. The length of the collection periods varied from 30 to 45 minutes. Venous blood was drawn at the mid point of the collection period. Urea was determined by the urease method as outlined by Peters and Van Slyke (1). The clearances are expressed in cubic centimeters of plasma cleared of urea per minute and are maximum clearances.

The normal clearances for Subjects 1, 2, 3 and 5 were made over a period of 3 weeks. Subject 4 was only available for 2 weeks. After the controls were obtained, vitamin A was administered daily. Subject 1 ingested capsules of carotene in oil, equivalent to 50,000 international units of vitamin A per day. Subjects 2 and 3 ingested the non-saponifiable fraction (N.S.F.) of halibut liver oil in Wesson oil equivalent to 45,000 units of vitamin A for 25 days, after which it was raised to 96,000 units of vitamin A. Subject 5 received the N.S.F. of halibut liver oil, equivalent to 175,000 units of vitamin A. Subject 4 received carotene, equivalent to 50,000

1 This study received support by financial grants from the Committee on Scientific Research of the American Medical Association and the Wisconsin Alumni Research Foundation. units and the N.S.F. equivalent to 100,000 units of vita$\min A$ per day. Subjects 7,8 and 9 received 50,000 units of vitamin $A$ in the form of halibut liver oil. Subjects $6,10,11,12$ and 13 received 60,000 units of vitamin $A$ in the form of halibut liver oil. No attempt was made to regulate the other portion of the dietary.

Serum vitamin A was determined in the first 9 subjects, using the procedure of van Eekelen (2) and the Lovibond tintometer. In the remaining subjects serum vitamin A was estimated by the procedure of Evelyn (3) and the photoelectric colorimeter. The serum samples were taken at the time of the clearance determination. The vision of 4 subjects in dim light, as tested by the bio-photometer, was followed throughout the experiment by the courtesy of Dr. Horace Getz. The visual measurements are expressed in milli-foot candles. The smaller the number, the better the dim vision. Oxygen consumption was determined by the Sanborn apparatus either during an actual clearance run or under similar conditions with the subject recumbent.

\section{RESULTS}

The normal clearance values are shown in Table I. The clearances are designated normal in the sense that there was no evidence of renal pathology and no particular attention had been given to the dietary vitamin A. However, Subjects $4,5,7,8,9$ and 10 have been found by Dr. Getz of the Department of Bacteriology to have subnormal dim vision as determined with the biophotometer. The clearances listed under vitamin A supplement are the highest values obtained on any one half day and with the exception of Subjects 4, 5, 6 and 7, two sets of values are included. Figure 1 shows all clearances as determined on 4 subjects before the vitamin A supplement was begun, during its administration and after its withdrawal. The serum for the vitamin A values in Table I was drawn at the time of the clearance determinations in Tables I and II.

The vitamin A must be administered for 2 or 3 weeks before any significant increase in urea clearance appears. About 8 weeks are required for the maximum response. This is illustrated by Subjects 1 and 2. After administration of the vitamin A supplement for 13 days, the increases 
in clearance were 5 and 4.4 per cent, respectively. After 25 days for Subject 1 there was no increase and for Subject 2 there was a 25 per cent increase. After 48 days, the increases were 24 and 27 per cent, respectively, and after 58 days, 34 and 65 per cent, respectively. Figure 1 also illustrates the changes in clearance with the administration and withdrawal of the vitamin A supplement.

In regard to the magnitude of the increase in clearance as the result of the large dosage of vita$\min A$, the subjects can be easily classified into 3 groups. One group composed of Subjects 7 and 8, Table I, showed a decrease or no effect. Another group composed of Subjects 3, 4, 5 and 6 had percentage increases ranging from 13 to 15 . The remaining subjects showed increases of 29 per cent or more. In 5 subjects the urea clearance rose above the generally accepted normal values. The constitutional type of the individual seems to be associated with the nature of the response to the administration of vitamin A. The 5 subjects showing the least response seemed to have little subcutaneous fat and their body weights usually fluctuated very little over a considerable period of time. On the other hand, the 8 subjects showing increases of 29 per cent or more carried larger amounts of subcutaneous fat and their body weights showed considerable fluctuation, depending upon the relative amounts of food consumption and physical activity. The subjects are arranged in the table in the order in which they were selected for the experiment. The Subjects $10,11,12$ and 13 were selected because their constitutional type indicated that they would probably give a good response. The data fulfill the prediction. The values for serum vitamin $\mathrm{A}$ indicate that the failure of the clearance to rise with administration of the vitamin is not because of a scarcity of circulatory vitamin A. This generalization is supported by a comparison of the data on Subjects 1 and 6, Subjects 2 and 5, and Subjects 8 and 9 . Subjects 1 and 6 attained about the same level of serum vitamin A but the former had a much larger increase in clearance than the latter. A similar comparison could be applied to Subjects 2 and 5.

The urea clearance cannot be maintained above a normal level indefinitely by administration of a large dosage of vitamin A. In Subject 1 the clearance was maintained at 100 or more for 70
TABLE I

Influence of vitamin $A$ upon urea clearance in the human subject

\begin{tabular}{|c|c|c|c|c|c|c|}
\hline \multirow{2}{*}{ Subject } & \multirow{2}{*}{$\begin{array}{c}\text { Body } \\
\text { surface } \\
\text { area M2 }\end{array}$} & \multicolumn{3}{|c|}{ Urea clearance } & \multicolumn{2}{|c|}{$\begin{array}{l}\text { Serum vitamin } A \\
\text { per } 1 \text { ce. }\end{array}$} \\
\hline & & $\begin{array}{c}\text { Fore } \\
\text { period } \\
\text { values }\end{array}$ & $\begin{array}{l}\text { Vitamin } \\
\text { A sup- } \\
\text { plement }\end{array}$ & Change & $\begin{array}{c}\text { Fore } \\
\text { period } \\
\text { values }\end{array}$ & $\begin{array}{l}\text { Maxi- } \\
\text { mum }\end{array}$ \\
\hline \multirow[t]{2}{*}{1} & 2.15 & $\begin{array}{r}114.0 \\
61.7 \\
64.7 \\
72.4 \\
75.6 \\
63.8 \\
63.3 \\
83.9 \\
109.6 \\
91.7\end{array}$ & $\begin{array}{l}108.1 \\
100.9 \\
126.1 \\
104.7 \\
113.2 \\
131.8\end{array}$ & per cent & $\begin{array}{c}c c . \text { of } \\
\text { per } \\
0.6 \mathrm{~B}\end{array}$ & $\begin{array}{l}\text { lasmo } \\
\text { inute } \\
0.97 \mathrm{~B}\end{array}$ \\
\hline & Average & $8 C .1$ & 114.1 & +42 & & \\
\hline \multirow[t]{2}{*}{2} & 1.94 & $\begin{array}{l}73.3 \\
61.0 \\
79.0 \\
60.1 \\
67.8 \\
65.2 \\
79.5 \\
67.8 \\
66.8\end{array}$ & $\begin{array}{r}94.3 \\
102.4 \\
99.6 \\
111.4 \\
93.5 \\
113.6 \\
127.0\end{array}$ & & $0.95 B$ & $1.6 \mathrm{~B}$ \\
\hline & Average & 68.9 & 106.0 & +53 & & \\
\hline \multirow[t]{2}{*}{3} & 1.80 & $\begin{array}{l}58.7 \\
58.4 \\
68.8 \\
67.5 \\
60.0 \\
49.3 \\
47.0 \\
58.0 \\
49.3 \\
50.7 \\
54.5\end{array}$ & $\begin{array}{l}64.9 \\
58.5 \\
66.8 \\
57.8 \\
69.5 \\
63.6 \\
62.3\end{array}$ & & $0.25 B$ & $0.90 \mathrm{~B}$ \\
\hline & $\overline{\text { Average }}$ & 56.5 & 63.3 & +12 & & . \\
\hline \multirow[t]{2}{*}{4} & 1.38 & $\begin{array}{l}36.2 \\
42.4\end{array}$ & $\begin{array}{l}44.3 \\
40.8 \\
49.3\end{array}$ & & & \\
\hline & Average & 39.3 & 44.8 & +14 & & \\
\hline \multirow[t]{2}{*}{5} & 1.88 & $\begin{array}{l}59.3 \\
68.1 \\
67.7 \\
60.5 \\
70.6 \\
66.5 \\
68.8\end{array}$ & $\begin{array}{l}70.6 \\
76.6 \\
73.2\end{array}$ & & $0.5 \mathrm{~B}$ & $1.6 \mathrm{~B}$ \\
\hline & Average & 65.9 & 73.4 & +11 & & \\
\hline \multirow[t]{2}{*}{6} & 1.80 & $\begin{array}{l}49.8 \\
44.9 \\
38.1 \\
45.7\end{array}$ & $\begin{array}{l}52.8 \\
50.2 \\
51.5\end{array}$ & & $0.44 B$ & $0.9 \mathrm{~B}$ \\
\hline & Average & 44.6 & 51.5 & +15 & & \\
\hline
\end{tabular}

B = Blue units on the Lovibond scale. 
TABLE I (Continued)

\begin{tabular}{|c|c|c|c|c|c|c|}
\hline \multirow{2}{*}{ Subject } & \multirow{2}{*}{$\begin{array}{c}\text { Body } \\
\text { surface } \\
\text { area M2 }\end{array}$} & \multicolumn{3}{|c|}{ Urea clearance } & \multicolumn{2}{|c|}{$\begin{array}{l}\text { Serum vitamin } A \\
\text { per } 1 \propto c .\end{array}$} \\
\hline & & $\begin{array}{l}\text { Fore } \\
\text { period } \\
\text { values }\end{array}$ & $\begin{array}{l}\text { Vitamin } \\
\text { A sup- } \\
\text { plement }\end{array}$ & Change & $\begin{array}{l}\text { Fore } \\
\text { period } \\
\text { values }\end{array}$ & $\begin{array}{c}\text { Maxi- } \\
\text { mum }\end{array}$ \\
\hline \multirow[t]{2}{*}{7} & 1.89 & $\begin{array}{l}65.4 \\
65.6 \\
68.1 \\
66.9 \\
63.2 \\
62.2 \\
63.3 \\
59.7\end{array}$ & $\begin{array}{l}53.2 \\
53.5 \\
67.7\end{array}$ & per cent & & \\
\hline & Average & 64.3 & 58.1 & -9 & & \\
\hline \multirow[t]{2}{*}{8} & 1.62 & $\begin{array}{l}49.5 \\
61.8 \\
52.8\end{array}$ & $\begin{array}{l}\mathbf{5 2 . 5} \\
49.6 \\
55.7 \\
50.8 \\
68.1 \\
53.6\end{array}$ & & $0.24 B$ & $1.1 \mathrm{~B}$ \\
\hline & Average & 54.7 & 55.0 & 0 & & \\
\hline \multirow[t]{2}{*}{9} & 1.76 & $\begin{array}{l}39.5 \\
37.6 \\
27.5\end{array}$ & $\begin{array}{l}\mathbf{5 8 . 0} \\
56.2 \\
\mathbf{5 6 . 4} \\
\mathbf{5 2 . 1} \\
\mathbf{5 4 . 7} \\
\mathbf{4 3 . 3}\end{array}$ & & $0.1 \mathrm{~B}$ & $0.7 \mathrm{~B}$ \\
\hline & Average & 34.8 & 53.4 & +53 & & \\
\hline \multirow[t]{2}{*}{10} & 2.04 & $\begin{array}{l}57.2 \\
52.3 \\
64.8 \\
62.8 \\
62.8 \\
61.7\end{array}$ & $\begin{array}{l}66.7 \\
77.3 \\
93.1 \\
81.8\end{array}$ & & $0.92 \mathrm{~L}$ & $2.8 \mathrm{~L}$ \\
\hline & Average & 60.2 & 79.7 & +32 & & \\
\hline \multirow[t]{2}{*}{11} & 2.18 & $\begin{array}{l}36.2 \\
49.0 \\
50.9 \\
35.7 \\
55.0\end{array}$ & $\begin{array}{r}85.2 \\
109.0 \\
76.5 \\
81.2 \\
82.0 \\
86.6\end{array}$ & & $0.92 \mathrm{~L}$ & $2.81 \mathrm{~L}$ \\
\hline & Average & 45.3 & 86.7 & +91 & & \\
\hline \multirow[t]{2}{*}{12} & 2.01 & $\begin{array}{l}48.0 \\
60.0 \\
51.5 \\
51.6 \\
48.2 \\
41.9\end{array}$ & $\begin{array}{l}75.0 \\
75.7 \\
63.7 \\
80.5 \\
73.2 \\
61.8\end{array}$ & & & $0.57 \mathrm{~B}$ \\
\hline & Average & 50.2 & 71.6 & +42 & & \\
\hline \multirow[t]{2}{*}{13} & 2.00 & $\begin{array}{l}73.2 \\
61.0 \\
77.5 \\
67.6 \\
63.9 \\
63.8\end{array}$ & $\begin{array}{l}83.1 \\
88.4 \\
72.9 \\
89.0 \\
98.9 \\
76.1\end{array}$ & & $1.6 \mathrm{~L}$ & $13.3 \mathrm{~L}$ \\
\hline & Average & 67.8 & 84.7 & +24 & & \\
\hline
\end{tabular}

$\mathrm{L}=\mathrm{L}$ units on the photoelectric colorimeter by the technique of Evelyn. days, after which it began to decline although vitamin A administration was continued. A similar observation had been made on dogs (4). In 7 subjects clearances were determined after withdrawal of the vitamin A supplement. In Subjects 2 and 3 the clearances approximated the normal within 18 days; in Subject 1 within 41 days; in Subject 10 within 64 days; in Subjects 11,12 and 13 the clearances remained 18 to 20 per cent above the normal within 93 days but approximated their normal within 128 days (Figure 1 ).

TABLE II

Influence of vitamin $A$ upon the average urea clearance, blood carotene and vitamin $A$ and the bio-photometer reading in the human subject

\begin{tabular}{|c|c|c|}
\hline Subjec & Normal & Excess A \\
\hline \multicolumn{3}{|l|}{1} \\
\hline & $\begin{array}{l}\text { Urea clearance } \ldots \ldots \ldots \ldots \ldots .81 \\
\text { Serum vitamin } \AA \ldots \ldots \ldots \ldots \ldots \\
\text { Milli-foot candles........ }\end{array}$ & $\begin{array}{l}109 \\
0.6 \mathrm{~B} \\
0.19\end{array}$ \\
\hline \multicolumn{3}{|l|}{2} \\
\hline & 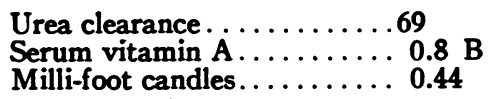 & $\begin{array}{l}105 \\
1.6 \mathrm{~B} \\
0.44\end{array}$ \\
\hline \multicolumn{3}{|c|}{-5} \\
\hline & 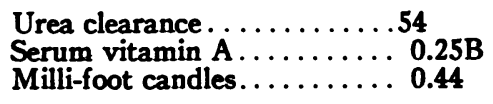 & $\begin{array}{l}65 \\
0.9 \text { B } \\
0.44\end{array}$ \\
\hline \multicolumn{3}{|l|}{4} \\
\hline & $\begin{array}{l}\text { Urea clearance } \ldots \ldots \ldots \ldots \ldots{ }^{39} \\
\text { Milli-foot candles...... }\end{array}$ & $\begin{array}{l}48 \\
1.5\end{array}$ \\
\hline
\end{tabular}

The mechanism by which vitamin A administration resulted in an elevation of urea clearance was of considerable interest. In the dog, vitamin A increased the volume of glomerular filtration, as determined by the inulin clearance (4). The question arose as to whether the increased clearance was due to a general improvement in the circulation rather than to a direct effect of the vitamin upon the kidney. Cardiac output would throw much light upon this question but in its determination we were unsuccessful. Arterial blood pressure was followed in 2 subjects but no change occurred. The oxygen consumption in Subject 1 averaged 5.1 per cent less when the urea clearance had increased 44 per cent as a result of the vitamin A supplement. In Subject 13 it was 5 per cent greater when the clearance was increased 32 per cent. These changes in oxygen usage are insignificant. 


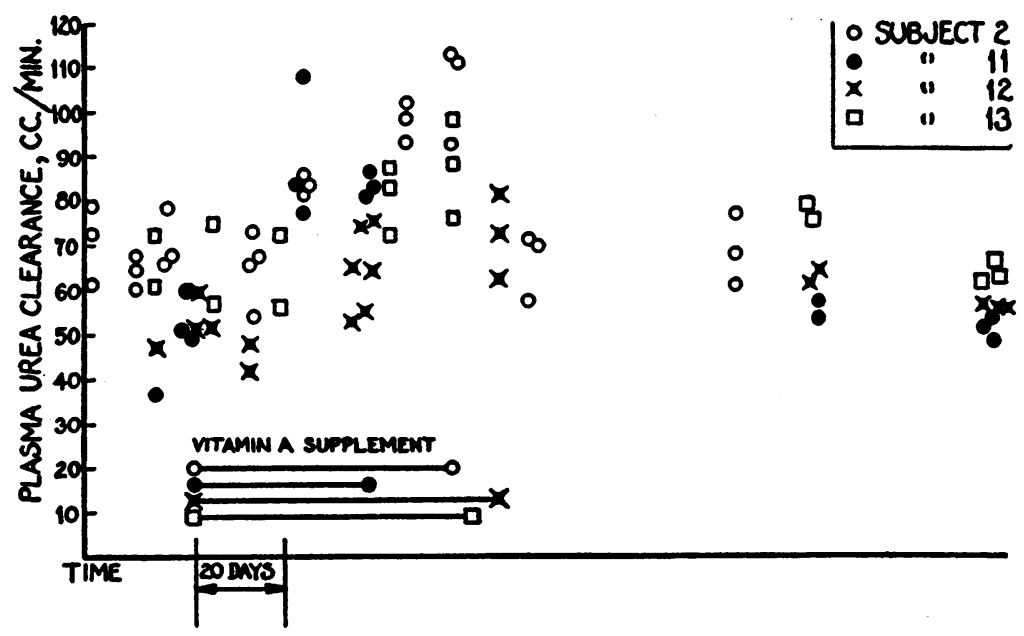

Fig. 1. Urea Clearance Before, During and After the Vitamin A SUPPLEMENT

A comparison of the effects of the vitamin A supplement upon serum vitamin $A, \operatorname{dim}$ vision and urea clearance is seen in Table II.

\section{COMMENT}

Although vitamin A does increase urea clearance in nearly all cases, the individual variability is striking and we have no explanation for it. Such variability was not found in the case of the $\operatorname{dog}(4)$ or rat (5). The limited data agree with the idea that the variability is associated with the constitutional type. The individual with the greater amount of subcutaneous fat, who gains or loses weight easily, is the type who is most likely to show an increase in urea clearance with vitamin A administration. It is interesting in this connection to note that, in the experimental animal, loss of subcutaneous fat is one of the early signs of avitaminosis. In 2 subjects the increased clearance was not accompanied by significant changes in arterial blood pressure or oxygen consumption. Therefore, changes in the general circulation are probably not responsible for the elevation of clearance.

As seen in Table II, improvement in dim vision does not necessarily accompany increased serum vitamin A or the elevation of urea clearance. Undoubtedly, many factors other than the supply of vitamin $A$ enter into the rate at which visual purple is regenerated.

\section{SUM MARY}

Vitamin A in the form of a concentrate of halibut liver oil or the entire oil was administered in daily doses varying from 50,000 to 75,000 international units to 10 male and 3 female adults. In 2 subjects there was no appreciable change in urea clearance, in 4 subjects the clearance increased 11 to 15 per cent, and in 7 subjects the clearance elevation ranged from 24 to 91 per cent. The subjects in this latter group were the type who easily gain in body weight. The increase in clearance in 2 subjects was not accompanied by significant changes in blood pressure or oxygen consumption.

\section{BIBLIOGRAPHY}

1. Peters, J. P., and Van Slyke, D.D., Quantitative Clinical Chemistry. Vol. II. Williams and Wilkins Company, Baltimore, 1932.

2. van Eekelen, M., Uber die Bestimmung von Vitamin $A$ in Körpersäften. Erwiderung auf die Witteilung von E. Rosenthal. Klin. Wchnschr., 1935, $14,829$.

3. Dann, W. J., and Evelyn, K. A., The determination of vitamin A with the photoelectric colorimeter. Biochem. J., 1938, 32, 1008.

4. Herrin, R. C., and Nicholes, H. J., The influence of vitamin $A$ upon urea and inulin clearance in the dog. Am. J. Physiol., 1939, 125, 786.

5. Herrin, R. C., Influence of vitamin A upon urea clearance in the rat. Proc. Soc. Exp. Biol. and Med. (In press). 